\title{
Association of Decreased T-Cell-Mediated Natural Cytotoxicity and Interferon Production in Down's Syndrome ${ }^{1}$
}

\author{
Madhavan P. N. NaIR ${ }^{2}$ And STANLey A. Schwartz \\ University of Michigan. Departments of Pediatric's and Epidemiology, Ann Arbor. Michigan 48109
}

\begin{abstract}
Total peripheral blood lymphocytes (PBL) and isolated subpopulations from children with Down's Syndrome (DS) and age-matched healthy controls were investigated for their (1) natural killer (NK) and antibody-dependent cellular cytotoxic activities. (2) interleukin 2 (IL-2)-induced augmentation of NK activity, (3) lectin-dependent cellular cytotoxicity (LDCC). (4) ability of serum- and culture-derived soluble suppressor factor(s) to inhibit NK activity of normal lymphocytes, and (5) capacity to produce interferon (IFN) against tumor targets in vitro. T lymphocytes from DS patients demonstrated significantly decreased NK activity against K 562 target cells compared to controls. DS lymphocytes also demonstrated a significant reduction in LDCC activity and IL-2-induced enhancement of NK activity. Furthermore, the ability of DS lymphocytes to produce IFN in vitro against K562 target celis was atso significantly lower than that for normal PBL. Although sera from DS patients showed a significantly greater inhibitory effect on the NK activity of allogeneic normal PBL than normal sera, culture supernates from DS lymphocytes demonstrated suppressive effects comparable to culture supernates from normal PBL. These studies suggest an association between the decreased NK activity of T-cell subpopulations and lower IFN production by PBL from patients with DS. 1984 Academic Press. Inc.
\end{abstract}

\section{INTRODUCTION}

An increased susceptibility to various infections and a high frequency of lymphoproliferative malignancies has been observed in patients with trisomy-21 or Down's Syndrome (DS) (1-6). Evidence of immune defects in DS include conflicting data on abnormal immunoglobulin levels $(7,8)$, deficiency of a cellular response $(9,10)$, thymic involution $(11,12)$, and lymphocyte depletion (13).

Recent studies suggest that natural killer (NK) cell and antibody-dependent cellular cytotoxic (ADCC) activities are important because of their possible role in defense against tumors and virus infections and in the regulation of various lymphocyte reactions $(14-18,20)$. It has been shown that patients with cancer exhibit significantly lower NK and ADCC activities, thus potentially predisposing the host to progressive discase. The high susceptibility of DS patients to various viral infections and to leukemia is of particular significance since it provides an opportunity to study their NK and ADCC functions before the onset of clinically

${ }^{1}$ Aided in part by National Institutes of Health Grants A 35922 and $\mathrm{Al} 19890$, the Children Leukemia Foundation of Michigan, and a grant from the Michigan Diabetes Research and Training Center, University of Michigan.

2 To whom requests for reprints should be sent: Department of Epidemiology. School of Public Health I, University of Michigan. Ann Arbor, Mich. 48109.

${ }^{3}$ Recipient of NIH Research Career Development Award CA 00896 
apparent disease. The present report examines the NK and ADCC activities and lectin- and interleukin 2 (IL-2)-induced cytotoxicity of DS lymphocytes in comparison with age-matched control lymphocytes from healthy donors. These studies demonstrate a significant defect in lectin- and IL-2-induced cytotoxicity and NK activity associated with purified T cells of DS patients. Our findings are consistent with previous reports of deficiencies of thymus-dependent immune functions in DS patients and may provide a cellular basis for the increased susceptibility to various infections and high risk of malignancies observed in DS.

\section{MATERIALS AND METHODS}

Patients. Thirteen noninstitutionalized children of both sexes with cytogenetically proven trisomy-21, ranging from 2 to 60 months of age, with a median age of 25 months, and five healthy age-matched normal donors, ranging from 2 to 56 months, with a median age of 24 months, were studied. Peripheral blood was drawn into a syringe containing $20 \mathrm{U} / \mathrm{ml}$ of heparin. Donors and their parents or guardians were apprised of the study and consents were obtained consistent with the policies of the University of Michigan and NIH.

Isolation of peripheral blood lymphocytes $(P B L)$. Mononuclear cells were isolated from heparinized venous blood using a modified method of Boyum (21). Blood was diluted with an equal volume of calcium- and magnesium-free Hanks balanced salt solution (HBSS) (GIBCO, Grand Island, NY) and centrifuged at $400 \mathrm{~g}$ for $30 \mathrm{~min}$ at $18^{\circ} \mathrm{C}$ over a cushion of Ficoll-Hypaque (Pharmacia Fine Chemicals, Piscataway, N.J.). The mononuclear cells band was harvested, washed three times with HBSS, and resuspended in RPMI 1640 medium, containing 25 $\mathrm{m} M$ Hepes buffer supplemented with $5 \%$ heat-inactivated fetal calf serum (FCS; GIBCO), $80 \mu \mathrm{g} / \mathrm{ml}$ gentamicin (Schering Corp., Kenilworth, N.J.), and $300 \mu \mathrm{g}$ of fresh glutamine per milliliter (complete medium).

Depletion of adherent cells. Mononuclear cells were depleted of adherent cells by the method of Ly and Mischell (22) as modified by Berlinger et al. (23). Total mononuclear cells were suspended in RPMI 1640 with $10 \%$ FCS and passaged through a 7-ml column of Sephadex G-10 beads (Pharmacia) equilibrated in the same medium. After $45 \mathrm{~min}$ of incubation at $37^{\circ} \mathrm{C}$, nonadherent cells (PBL) were washed through with one bed volume of warm $\left(37^{\circ} \mathrm{C}\right)$ medium. The cell recovery was $>70 \%$ of the total input, and monocyte contamination as indicated by nonspecific esterase staining was $<2 \%$.

Preparation of $T$ cells. T cells were prepared as described elsewhere (24). Briefly, $4 \times 10^{6} \mathrm{PBL}$ depleted of adherent cells were mixed with $0.25 \mathrm{ml}$ of FCS absorbed with sheep red blood cells (SRBC) and $1 \mathrm{ml}$ of $1 \%$ packed volume of neuraminidase-treated $(25 \mathrm{U} / \mathrm{ml}$ in a $5 \% \mathrm{SRBC}$ suspension) SRBC. The mixture was incubated at $37^{\circ} \mathrm{C}$ for $5 \mathrm{~min}$ and centrifuged at $200 \mathrm{~g}$ for $5 \mathrm{~min}$, followed by incubation al $4^{\circ} \mathrm{C}$ for $1 \mathrm{hr}$. The pellets were gently resuspended and $\mathrm{T}$ lymphocytes rosetted with SRBC were separated from non-T lymphocytes on a Ficoll-Hypaque (Pharmacia) density gradient by centrifugation at $480 \mathrm{~g}$ for $20 \mathrm{~min}$ at $20^{\circ} \mathrm{C}$. $\mathrm{SRBC}$ attached to the isolated $\mathrm{T}$ lymphocytes (pellet) were lysed by hypotonic treatment with $1 \mathrm{ml}$ of distilled water for $20 \mathrm{sec}$, followed by $1 \mathrm{ml}$ of doublestrength minimal essential medium (MFM; GIBCO). T cells were washed three 
times with RPMI 1640 and resuspended in complete medium and preincuhated for $24 \mathrm{hr}$ before use.

Preparation of target cells. As targets, a highly sensitive human erythroleukemia cell line, K562, was used in the NK assay. For the ADCC assay, antibodycoated SB cells derived from a patient with a B-cell leukemia served as targets. In vitro passaged 48 -hr-old target cells were harvested and washed twice with complete medium. To $0.8-\mathrm{ml}$ aliquots of complete medium containing $5 \times 10^{6}$ tumor cells, $200 \mu \mathrm{Ci}$ of ${ }^{51} \mathrm{Cr}$ as sodium chromate (New England Nuclear, Boston. Mass.) was added. The cells were incubated at $37^{\circ} \mathrm{C}$ for $1 \mathrm{hr}$ in a humidified atmosphere of $5 \% \mathrm{CO}_{2}$ in air with intermittent shaking. Following incubation, the cells were washed three times with complete medium and resuspended to a concentration of $2 \times 10^{5}$ cells $/ \mathrm{ml}$.

Assay for NK activity. NK activity was determined in a direct ${ }^{51} \mathrm{Cr}$-release assay as previously described $(18,20)$. A fixed number of viable effector cells in complete medium were added to triplicate cultures of ${ }^{51} \mathrm{Cr}$-labeled target cells in final volumes of $0.2 \mathrm{ml}$ in V-bottom microtitration plates (Dynatech Labs. Alexandria, Va). After centrifugation at $40 \mathrm{~g}$ for $2 \mathrm{~min}$, they were incubated at $37^{\circ} \mathrm{C}$ in a humidified atmosphere of $5 \% \mathrm{CO}_{2}$ in air for $4 \mathrm{hr}$. Percentage cytotoxicity was calculated as

$$
\% \text { cytotoxicity }=\frac{\text { experimental release }- \text { spontaneous release }}{\text { total release }- \text { spontaneous release }} \times 100,
$$

where spontaneous release represents counts released from control wells containing only $2 \times 10^{4}$ target cells, and total release represents counts obtained in an aliquot of $2 \times 10^{4}$ lysed target cells.

Assay for ADCC. The ADCC activity of effector cells was determined by the original method of Perlmann and Perlmann (25) as modified by Handwerger and Koren (26). Briefly, $50 \mu \mathrm{l}$ of varying concentrations of effector cells was added to $50 \mu \mathrm{l}$ of complete medium containing ${ }^{51} \mathrm{Cr}$-labeled SB target cells and $100 \mu \mathrm{l}$ of a $2 \times 10^{-4}$ dilution of rabbit anti-SB antisera previously found to yield maximal ADCC. Percentage cytotoxicity of ADCC activity was calculated as described above for NK activity with the following exceptions. Spontaneous release represents counts released in control wells containing effector cells, labeled SB target cells, and medium instead of anti-SB antibodies, and total release represents counts obtained in an aliquot of $1 \times 10^{4}{ }^{51} \mathrm{Cr}$-labeled SB target cells.

Target binding assay. A target binding assay was used as described by Haliotis et al. (27). In brief, lymphocytes were washed twice and mixed with a fivefold excess of tumor cells, centrifuged at $150 \mathrm{~g}$ for $5 \mathrm{~min}$ and incubated at $37^{\circ} \mathrm{C}$ for 5 min. Following incubation, lymphocyte-target mixtures were transferred to ice. the pellets were gently resuspended, and the number of lymphocytes binding to tumor targets was determined using a hemocytometer.

Interleukin 2. Commercially available IL-2 (Electro-Nucleonics Labs, Inc.. Silver Spring, Md.) was diluted in RPMI 1640 and stored at $-70^{\circ} \mathrm{C}$ before use. The maximum NK augmenting dose (10\% final concentration) as previously determined was used. 
Treatment of effector cells with $I L-2$. PBL $\left(2 \times 10^{6} / \mathrm{ml}\right)$ were washed and suspended in $1 \mathrm{ml}$ of RPMI 1640 plus 5\% FCS to which IL-2 (10\% v/v), previously found to yield a maximum NK augmenting effect, was added. The cultures were incubated for $24 \mathrm{hr}$ at $37^{\circ} \mathrm{C}$ in a humidified atmosphere of $5 \% \mathrm{CO}_{2}$ in air, washed twice, and resuspended in medium. Control cultures were treated identically with the exception that IL-2 was not added. Viability of treated lymphocytes was unaffected as assessed by trypan blue dye exclusion. Both treated and control cultures were assayed for NK activity.

Lectin-dependent cell-mediated cytotoxicity assay (LDCC). The LDCC assay was carried out similarly to the NK assay. Briefly, target and effector cells were added to V-bottom microtitration plates, and various concentrations of phytohemagglutinin-P (Difco Laboratories, Detroit, Mich.), 0.5, 1, and $2.5 \mu \mathrm{g} / \mathrm{ml}$, were added to a final volume of $0.2 \mathrm{ml}$ and incubated for $4 \mathrm{hr}$ at $37^{\circ} \mathrm{C}$ in humidified $5 \% \mathrm{CO}_{2}$ incubator. Percentage LDCC activity was calculated as described for the NK activity and was compared with cytotoxicity observed with control cultures containing effector and target cells. Percentage cytotoxicity was calculated as

$$
\% \text { cytotoxicity }=\frac{\text { experimental release }- \text { spontaneous release }}{\text { total release }- \text { spontaneous release }} \times 100,
$$

where spontaneous release represents counts released from control wells containing $2 \times 10^{4}$ target cells plus lectin, and total release represents counts obtained from $2 \times 10^{4}$ lysed target cells.

Preparation of soluble suppressor factors (SSF). SSF were prepared as previously described $(19,20)$. Briefly mononuclear leukocytes from either normal donors or DS patients after being washed three times with normal saline were resuspended in RPMI 1640 medium containing only gentamicin and glutamine. Suspensions of $5 \times 10^{6}$ cells $/ \mathrm{ml}$ were incubated at $37^{\circ} \mathrm{C}$ in a humidified atmosphere of $5 \% \mathrm{CO}_{2}$ in air for 5 days. After incubation, supernates were separated by centrifugation at $500 \mathrm{~g}$ for $30 \mathrm{~min}$ and stored at $-20^{\circ} \mathrm{C}$. Control supernates prepared in the absence of cells were treated similarly and termed mock SSF.

Incubation of effector cells with SSF. Duplicate sets of cultures containing 2 $\times 10^{6} \mathrm{PBL}$ in $0.8 \mathrm{ml}$ of RPMI 1640 plus glutamine, gentamicin, and $5 \%$ FCS were added to a tube containing $200 \mu \mathrm{l}$ of SSF or mock SSF $(20 \% \mathrm{v} / \mathrm{v})$ and incubated in a humidified environment of $5 \% \mathrm{CO}_{2}$ in air at $37^{\circ} \mathrm{C}$ for $72 \mathrm{hr}$. Cells were then washed twice and resuspended in complete medium. Cell viability in SSF-treated cultures was comparable with that of mock SSF-treated cultures as determined by trypan blue dye exclusion and was found to be 80 to $90 \%$. Treated and control cultures were tested for their ability to mediate NK activity.

Interferon (IFN) assay. Lymphocytes were cultured alone or with $\mathrm{K} 562$ target cells at a ratio of $100: 1$ for $18 \mathrm{hr}$ at $37^{\circ} \mathrm{C}$ in $5 \% \mathrm{CO}_{2}$ in air, after which they were centrifuged and the supernates were collected for IFN assay. Supernates were quantitated for IFN using the modified colorimetric assay of Borden and Leonhardt (28). Briefly, 96-well flat-bottom microtitration plates (Costar, Cambridge, Mass.), were seeded with human epithelial cells (WISH) at a concentration of 3 $\times 10^{4}$ cells/well in $0.1 \mathrm{ml}$ of medium and incubated for $18 \mathrm{hr}$. Serial dilutions of 
supernates $(1: 10,1: 40,1: 160$, and $1: 320)$ were added in $0.1 \mathrm{ml}$ and incubated again for $8 \mathrm{hr}$. The cells were then infected with vesicular stomatitis virus (VSV), 200 plaque forming units/well, for $24 \mathrm{hr}$. After development of cytopathic effect, cultures were washed with PBS and overlaid with $0.2 \mathrm{ml}$ of $0.015 \%$ neutral red in saline and incubated for $2 \mathrm{hr}$ at $37^{\circ} \mathrm{C}$. The monolayers were washed and the cellular dye was eluted with a 1:1 solution of absolute ethanol:0.2 $\mathrm{M} \mathrm{NaH}_{2} \mathrm{PO}_{4}$. As a control, an IFN preparation standardized against NIH reference G023-90) 527 of known concentrations ranging from 2 to $300 \mathrm{U} / \mathrm{ml}$ was included in the assay. This assay is highly reproducible and can detect as little as $4 \mathrm{U} / \mathrm{ml}$ of IFN.

\section{RESULTS}

\section{NK and ADCC Activities of Lymphocytes from DS Patients}

NK and ADCC effector cells have been shown to be important in immune surveillance against neoplasia. Since DS patients show increased susceptibility to leukemia, various subpopulations of mononuclear cells from these patients were tested for their NK and ADCC activities against target cells at different effector to target $(\mathrm{E}: \mathrm{T})$ ratios. Data presented in Table 1 demonstrate that. although total unfractionated PBL from DS patients consistently show decreased NK and ADCC activities at different E:T cell ratios. these values were not statistically different from those for normal PBL.

As previous studies have suggested defects in cell-mediated immunity among DS patients, we specifically examined the NK activity of purified T lymphocytes from patients with trisomy-2l and compared this with $T$ cells isolated from agematched normal donors. Table 2 demonstrates that $T$ lymphocytes from DS pa tients are significantly decreased in NK activity (19\%) compared to the higher cytotoxicity $(41 \%)$ displayed by normal T lymphocytes $(P<0.025)$. Non-T cells from normal and DS donors, however, showed higher and comparable NK ac-

TABLE 1

NK AND ADCC ACTIVITIES OF NORMAL AND DOWN'S SYNDROME LyMPHOCYTES"

\begin{tabular}{|c|c|c|c|c|c|}
\hline \multirow[b]{2}{*}{ Target } & \multirow[b]{2}{*}{ Effector souree } & \multicolumn{4}{|c|}{ Effector:target cell ratio } \\
\hline & & $50: 1$ & $25: 1$ & $10: 1$ & $5: 1$ \\
\hline \multicolumn{6}{|c|}{ \& Cytotoxicity } \\
\hline \multirow[t]{2}{*}{$\mathrm{K} 562^{c}$} & Normals & $44.1 \pm 13.7$ & $31.8 \div 8.4$ & $17.4 \pm 5.8$ & $89 \pm 2.3$ \\
\hline & DS & $25.7 \pm 15.5$ & $26.0 \pm 15.3$ & $14.5 \pm 10.0$ & $49 \pm 5.9$ \\
\hline \multirow[t]{2}{*}{$\mathrm{SB}^{d}$} & Normals & $41.7 \pm 14.7$ & $33.9+16.8$ & $23.0 \pm 11.8$ & $13,3=4,3$ \\
\hline & DS & $23.6 \pm 16.2$ & $19.2 \pm 11.6$ & $13.3 \pm 6.2$ & $9.7 \div 3.9$ \\
\hline
\end{tabular}

"Effector cells were depleted of phagocytic cells and mixed with target cells as detailed under Materials and Methods at varying E:T cell ratios in a $4-\mathrm{hr}{ }^{51} \mathrm{Cr}$-release assay. The results are the means \pm SD performed in triplicate of 13 separate patients and 5 age-matched normal donors

${ }^{b}$ Percentage cytotoxicity was calculated as under Materials and Methods.

' Erythroleukemia cell line used as targets in NK assay.

${ }^{d}$ B-Leukemia cell line sensitized with anti-SB antibody used as targets in ADCC assay. Differences in values between the normals and DS patients were not statistically significant at any $E$ : $T$ cell ratio in both NK and ADCC assays using single-tailed Student's t test. 
TABLE 2

NK ACTIVITY OF T-LyMPHOCYTE SUBPOPULATIONS ${ }^{a}$

\begin{tabular}{ccc}
\hline \multirow{2}{*}{ Lymphocyte source } & \multicolumn{2}{c}{$\%$ Cytotoxicity $^{b}$} \\
\cline { 2 - 3 } Normal & T cells $^{c}$ & Non-T cells $^{d}$ \\
DS & $41.2 \pm 6.4^{e}$ & $58.2 \pm 5.1$ \\
& $(P<0.025)$ & $(P<0.1)$ \\
& $19.5 \pm 4.2$ & $54.5 \pm 5.6$ \\
\hline
\end{tabular}

${ }^{a} \mathrm{~T}$ cells were isolated by rosetting with neuraminidase-treated SRBC. as described under Materials and Methods.

$b \%$ Cytotoxicity was calculated as under Materials and Methods.

c $T$ cells contained $>92 \%$ E-rosette-positive cells, $<0.05 \%$ fluorescent, polyvalent surface Igbearing cells, and $<1 \%$ nonspecific esterase-positive and latex-ingesting phagocytic cells.

${ }^{d}$ Non-T cells are lymphocytes separated from rosetted $\mathrm{T}$ cells on a Ficoll-Hypaque gradient. Non-T cells contained $<2 \%$ E-rosette-positive cells and $<0.5 \%$ nonspecific esterase-positive and latex-ingesting cells.

${ }^{e}$ Results are means \pm SD of 3 experiments performed at 50:1 E:T cell ratio. Statistical values were determined by single-tailed Student's $t$ test.

tivity, 58 and $54 \%$, respectively. Examination of the target binding ability of mononuclear cells showed that lymphocytes from DS patients exhibit a normal range of target binding capacity against K562 targets compared to that of control lymphocytes (Table 3 ).

\section{Effect of IL-2 on NK Activity of DS Lymphocytes}

We investigated whether IL-2 could augment the cytotoxicity of DS lymphocytes to the same level shown by normal lymphocytes. Data presented in Table 4 demonstrate that normal PBL precultured with IL-2 showed $61 \%$ cytotoxicity compared to $20 \%$ cytotoxicity displayed by untreated cultures. DS lymphocytes precultured with IL-2 demonstrated an increased cytotoxicity (38\%) compared to that of untreated lymphocytes (21\%). The percentage enhancement of IL-2-induced cytotoxicity of DS lymphocytes was significantly lower (82\%) compared with that of normal lymphocytes $(197 \%)(P<0.0025)$. This indicates that, although the cytotoxicity of DS lymphocytes could be enhanced considerably by IL-2, the cytotoxic potential was not augmented to the levels shown by normal lymphocytes.

\section{Effect of Lectin on Cellular Cytotoxicity (LDCC) of DS Lymphocytes}

Since DS lymphocytes demonstrated reduced IL-2-induced cytotoxic potential, we examined whether their cytotoxicity could be activated with lectin to the levels shown by normal lymphocytes. Data presented in Table 5 demonstrate that normal PBL at an E:T ratio of 50:1 produced 40,46 , and $45 \%$ LDCC activity against SB targets at $0.5,1$, and $2.5 \mu \mathrm{g} / \mathrm{ml}$ of PHA, respectively, compared to $7 \%$ cytotoxicity observed in the absence of PHA. PBL from DS patients showed 5\% cytotoxicity without PHA; cytotoxicity was considerably enhanced to 13,14 , and $15 \%$ by PHA at $0.5,1$, and $2.5 \mu \mathrm{g} / \mathrm{ml}$ concentrations, respectively. Although PHA could significantly enhance the cytotoxicity of DS lymphocytes, activity was not en- 
TABLE 3

Target Binding Ability of Lymphocytes from Patien's with Down's Syndrome and NORMAL, CONTROL $S^{\prime \prime}$

\begin{tabular}{clc}
\hline Expt & Effector source & $\begin{array}{c}\text { Target-binding } \\
\text { lymphocytes } \\
(\%)\end{array}$ \\
\hline 1 & Normal & 13 \\
2 & DS (LC) & 14 \\
& Normal & 15 \\
& DS (PR) & 13 \\
& Normal & 13 \\
\hline
\end{tabular}

${ }^{\circ}$ Effector and target cells were mixed at an E:T ratio of $5: 1$ and incubated at $37^{\circ} \mathrm{C}$ for $30 \mathrm{~min}$. followed by $0^{\circ} \mathrm{C}$ for $1 \mathrm{hr}$. Aliquots were examined in a hemocytometer and a positive target-binding cell was scored for each lymphocyte binding two or more target cells.

${ }^{b}$ The human erythroleukemia cell line, K562. was used as target in binding study.

hanced to the levels shown by normal PBL. For example, normal PBL demonstrated 464,550 , and $538 \%$ enhancement of their residual cytotoxicity compared to significantly reduced enhancement of $157(P<0.05), 189(P<0.005)$, and $214 \%(P<0.0025)$ shown by DS lymphocytes at $0.5,1$, and $2.5 \mu \mathrm{g} / \mathrm{ml}$ concentrations of PHA, respectively.

\section{Interferon Production by DS Lymphocytes In Vitro}

Since earlier studies (29) demonstrated a reduced augmentation of IFN-induced NK activity of DS lymphocytes compared to normal lymphocytes, we examined the ability of DS lymphocytes to produce IFN against K562 target cells in vitro. Data presented in Table 6 demonstrate that DS lymphocytes produced significantly lower levels of IFN $(1443 \pm 223 \mathrm{U} / \mathrm{ml})$ compared to those of normal lymphocytes $(2675 \pm 120 \mathrm{U} / \mathrm{ml})(P<0.005)$.

TABLE 4

EFFECT OF INTERLEUKIN 2 ON NK ACTIVITY OF DS LYMPHOCYTES ${ }^{\prime}$

\begin{tabular}{lcccc}
\hline & \multicolumn{2}{c}{$\%$ Cytotoxicity $^{b}$} & \\
\cline { 2 - 4 } $\begin{array}{c}\text { Effector } \\
\text { source }\end{array}$ & $\begin{array}{c}\text { Medium } \\
\text { control }\end{array}$ & $+\mathrm{IL}-2$ & $\%$ Enhancement \\
\hline Normals & $20.6 \pm 3.2^{\prime \prime}$ & $61.2 \pm 5.8$ & 197.7 \\
DS & $20.9 \pm 2.3$ & $38.0 \pm 2.3$ & $(P<.0025)$ & 81.8 \\
\hline
\end{tabular}

${ }^{a}$ Lymphocytes $\left(2 \times 10^{6}\right)$ depleted of adherent cells were cultured alone or with IL-2 (10\% v/v) for $24 \mathrm{hr}$, washed, and tested for their NK activity against K562 target cells at an E:T cell ratio of 20:1.

$b \%$ Cytotoxicity was calculated as under Materials and Methods.

$c$ Enhancement was calculated on the basis of cytotoxicity obtained when lymphocytes were precultured in medium alone.

${ }^{d}$ Values represent mean $\%$ cytotoxicity \pm SD of 4 separate experiments done in triplicate. Statis. tical significance was determined using a single-tailed Student's $t$ test. 
TABLE 5

EfFect of Lectin on CellulaR Cytotoxicity of DS Lymphocytes ${ }^{a}$

\begin{tabular}{lcccc}
\hline & \multicolumn{4}{c}{ PHA concentration $(\mu \mathrm{g} / \mathrm{ml})$} \\
\cline { 2 - 5 } $\begin{array}{c}\text { Lymphocyte } \\
\text { source }\end{array}$ & 0 & 0.5 & 1 & 2.5 \\
\hline \multicolumn{5}{c}{ \% Cytotoxicityc } \\
Normals & $7.1 \pm 1.4^{d}$ & $40.1 \pm 8.9(464.7)$ & $46.2 \pm 5.2(550.7)$ & $45.3 \pm 5.4(538.0)$ \\
DS & $4.9 \pm 2.4$ & $P<0.05$ & $P<0.005$ & $P<0.0025$ \\
& $12.6 \pm 5.2(157.1)$ & $14.2 \pm 3.1(189.1)$ & $15.4 \pm 2.1(214.2)$ \\
\hline
\end{tabular}

${ }^{a}$ The lectin-dependent cellular cytotoxicity assay was carried out similarly to the NK assay except the NK-resistant SB cell line was used as target as described under Materials and Methods.

${ }^{b}$ Lymphocytes depleted of adherent cells.

c\% Cytotoxicity was calculated as described under Materials and Methods.

${ }^{d}$ Values represent mean $\%$ cytotoxicity \pm SD of 4 separate experiments employing 4 DS patients and 4 age-matched controls. Experiments were performed in triplicate at a 50:1 E:T cell ratio. Statistical values were determined by single-tailed Student's $t$ test. Values in parentheses are \% enhancement of cytotoxicity.

\section{Effect of Soluble Factors on NK Activity of Normal Lymphocytes}

We examined the effect of SSF on the NK activity of fresh allogeneic cells derived by preculturing DS lymphocytes. The results show (Table 7) that normal lymphocytes precultured with SSF prepared from healthy allogeneic donors demonstrated $21.5 \%$ cytotoxicity compared to $37 \%$ cytotoxicity shown by mock SSF (42.2\% suppression). Lymphocytes precultured with SSF prepared from DS lymphocytes also demonstrated a significant decrease in their NK activity (22.7\%) compared to the cytotoxicity (37.2\%) obtained when lymphocytes precultured with mock SSF ( $38.9 \%$ suppression). This suggests that the immunoregulatory functions of suppressor cells and their soluble products in DS patients are comparable to those of normal healthy subjects.

TABLE 6

INTERferon Production by Lymphocytes from DS Patients and Normal Donors ${ }^{a}$

\begin{tabular}{lc} 
Culture composition & $\begin{array}{c}\text { Interferon activity } \\
(\mathrm{U} / \mathrm{ml})\end{array}$ \\
\hline Normal lymphocytes & $<8$ \\
DS lymphocytes & $<8$ \\
Target cells & $<8$ \\
Normal lymphocytes & \\
$\quad$ target cells (K562) & $2675 \pm 120$ \\
DS lymphocytes + & $(P<0.005)$ \\
target cells (K562) & $1443 \pm 223$ \\
\hline
\end{tabular}

\footnotetext{
"Supernates were obtained from cell cultures incubated for $18 \mathrm{hr}$ at $37^{\circ} \mathrm{C}$ in a $5 \% \mathrm{CO}_{2}$ atmosphere. Mixtures of effector and target cells were set up at 100:1 E:T cell ratios (previously determined to yield maximum IFN). IFN in the supernates was assayed as detailed under Materials and Methods. Results are means \pm SD of 3 experiments. Statistical values were determined by single-tailed Student's $t$ test.
} 
TABLE 7

Production of Soluble SupPressor Factors by Lymphocy tes from DS PATIENTS AND NORMAL DONORS ${ }^{a}$

\begin{tabular}{lcc}
\hline $\begin{array}{c}\text { Source of } \\
\text { supernates }^{b}\end{array}$ & $\begin{array}{c}\text { Cytotoxicity } \\
(\%)\end{array}$ & Suppression $^{i}$ \\
\hline Mock SSF & $37.2 \pm 3.1^{+}$ & - \\
Normal lymphocytes & $21.5 \pm 7.1$ & 42.2 \\
DS lymphocytes & $22.7 \pm 9.0$ & 38.9 \\
\hline
\end{tabular}

" $\Lambda$ llogeneic normal adult lymphocytes $\left(2 \times 10^{6}\right)$ depleted of adherent cells were cultured in complete medium supplemented with a $20 \%(\mathrm{v} / \mathrm{v})$ concentration of either a medium control or supernates from precultured DS lymphocytes or age-matched normal PBL. After $72 \mathrm{hr}$ the cells were examined for NK activity against K.562 cells.

${ }^{b}$ Supernates of lymphocytes cultured for 4 days at $37^{\circ} \mathrm{C}$ in $5 \% \mathrm{CO}_{2}$ in air, was used as a source of soluble suppressor factor.

c Cytotoxicity was calculated as under Materials and Methods.

${ }^{d}$ Suppression of cytotoxicity was calculated as under Materials and Methods.

Medium incubated in absence of lymphocytes.

$f$ Values represent mean \% cytotoxicity \pm SD of 4 separate experiments done in triplicate at at $50: 1$ E:T cell ratio.

\section{Sera from DS Patients Inhibit NK Activities of Normal Lymphocytes}

Studies by ourselves $(30)$ as well as others $(31,32)$, demonstrated that normal serum contains inhibitory factors directed against NK and ADCC functions of normal autologous and allogeneic PBL, and that these inhibitory factors are significantly higher in sera from a variety of cancer patients. We investigated the ability of DS serum to inhibit NK activity of allogeneic PBL from normal donors. The data presented in Table 8 demonstrate that four of five samples of DS serum significantly inhibited the NK activity of normal PBL compared to that of normal serum.

\section{DISCUSSION}

Because of the increased predisposition of patients with DS to infections and leukemia, analysis of their immune status is an important clinical parameter. Deficiencies of both humoral immunity and cell-mediated immunity have been implicated in the syndrome, although the underlying cellular mechanisms remain unclear. Lopez et al. (33) demonstrated a defect in specific antibody synthesis to bacteriophage in vivo in DS patients. A high incidence of autoantibodies $(34,35)$ and increased susceptibility to hepatitis viruses (36) have also been reported. Burgio and Nespoli (37) showed that both thymus-dependent and independent functions were impaired in DS patients with a characteristic chronologic sequence. Nurmi et al. (38) observed a lower antibody response to pneumococcal vaccine in DS patients. Segar et al. (39) and Serra et al. (40) reported that the transformation responses of trisomic lymphocytes to PHA decreased with age. Thymic abnormalities $(11,12)$ and deficiencies in the number and functions of $T$ lymphocytes (37) have also been demonstrated. Nurmi et al. (29) recently observed normal NK and ADCC reactions in unseparated lymphocyte populations in adult DS patients compared to lymphocytes from normal donors. We have 
made a similar observation in children with DS as reported herein. However, when $\mathrm{T}$ lymphocytes from DS patients are separated from other mononuclear subpopulations and specifically examined for NK activity they manifest significant deficiencies when compared to $T$ cells from normal donors. Thus this subtle defect could be overlooked if only total lymphocytes are examined and only becomes manifest upon isolation of $\mathrm{T}$ cells. Previous investigations suggest that $\mathrm{T}$ cells are involved in $\mathrm{NK}$ and $\mathrm{ADCC}$ mechanisms $(41,42)$ as well as in the regulation of other immunologic reactions $(42-44)$. It has also been proposed that NK cells have characteristics of pre-T cells $(45,46)$. The decreased NK activity of $\mathrm{T}$ cells from DS patients is unlikely due to either increased or decreased sensitivity of DS T lymphocytes to rosetting and hypotonic treatment compared to normal $\mathrm{T}$ cells. Rosetting and hypotonic shock is a well-established method for obtaining viable and functionally active $T$ cells (47). When $T$ cells from DS patients and controls were isolated by this technique, both populations were equally viable $(>97 \%)$ as tested by trypan blue dye exclusion and contained $<1 \%$ nonspecific esterase-positive cells. Furthermore, T-cell populations were preincubated for $24 \mathrm{hr}$ in complete medium at $37^{\circ} \mathrm{C}$ in $5 \% \mathrm{CO}_{2}$ in air to allow shedding of bound RBC fragments, turn over of newly synthesized membrane receptors, and equilibration of functional activities. When experiments are set up, equal numbers and concentration of viable cells from both DS patients and controls were run simultaneously. The decreased NK activity of T lymphocytes from DS patients as observed in the present study may represent yet another example of a functional deficiency of T-cell maturation or differentiation in these patients which may lead to increased susceptibility to various infections and leukemia.

Sera from cancer patients appear to contain suppressor factors capable of inhibiting NK and ADCC reactions (30-32). Analysis of serum factors that can inhibit NK activity may thus be relevant to host resistance to certain infections and tumor growth. In the present investigation, sera from DS patients showed significant inhibitory effects on the NK functions of normal PBL (Table 8). This suggests that the immunodeficiency observed in DS may be correlated with the development of SSF. The ability of DS serum to suppress the NK activity of normal lymphocytes in vitro may reflect similar inhibitory effects on NK effector cells in vivo. Therefore increases in SSF activity in the sera of DS patients may predispose them to various infections and possibly to malignancy.

NK cells appear to have some selectivity since certain targets are very susceptible whereas others are resistant. This may be due to differences in the antigenic structures present on target cells or the receptor sites on NK cells or both. It has been demonstrated that lymphocyte cytotoxicity can be activated by lectin (PHA). The exact function of lectin activation is not presently understood, but it has been suggested that it may act directly on cytotoxic cells by rearranging cryptic receptors for recognition sites on target cells, providing sufficient signals to trigger subsequent lytic events $(48,49)$. In the present report the cytotoxicity of DS lymphocytes could be considerably enhanced by PHA, even though cytotoxicity could not be stimulated to the levels shown by normal PBL (Table 5), suggesting a defect in the LDCC activity of DS lymphocytes. 
TABLE 8

Suppression of NK Activities of Normal Al.logeneic Lymphocytes by Serum from DS PATIENTS AND NORMAI, DONORS ${ }^{t}$

\begin{tabular}{|c|c|c|c|}
\hline \multirow[b]{2}{*}{ Serum source } & \multicolumn{3}{|c|}{ Concentration of serum (viv) } \\
\hline & $5 \%$ & $10 \%$ & $20 \%$ \\
\hline \multicolumn{4}{|c|}{ \% Cytotoxicity } \\
\hline Normal 1 & 40.0 & 35.0 & 20.1 \\
\hline Normal 2 & 34.3 & 31.1 & 29.6 \\
\hline Normal 3 & 42.2 & 38.4 & 30.2 \\
\hline Normal 4 & 33.0 & 31.0 & 29.2 \\
\hline DS1 & $40.4(-7.2)$ & $22.9(32.2)$ & $11.08(63.3)$ \\
\hline DS 2 & $18.0(51.7)$ & $15.8(53.2)$ & $10.3(65.8)$ \\
\hline DS 3 & $21.4(42.6)$ & $20.3(39.9)$ & $15.5(48.6)$ \\
\hline DS 4 & $25.2(32.4)$ & $24.1(28.6)$ & $20.4(32.4)$ \\
\hline DS 5 & $33.4(10.4)$ & $\mathrm{ND}^{\prime}$ & $31.7\{-4.9\}$ \\
\hline
\end{tabular}

${ }^{a}$ Allogeneic normal adult PBL depleted of adherent cells were precultured separately with either DS serum or age-matched normal serum (heat inactivated for $30 \mathrm{~min}$ at $56^{\circ} \mathrm{C}$ ) at a 5,10 , and $20 \%$ final concentration for $24 \mathrm{hr}$ in a $5 \% \mathrm{CO}_{2}$ incubator. After washing, viable cells were tested for their NK activity at a 50:1 E:T cell ratio as described under Materials and Methods. The erythroleukemia cell line, K562, was used as targets for NK activity.

${ }^{b}$ Percentage cytotoxicity was calculated as under Materials and Methods.

${ }^{c}$ Numbers in parentheses are \% suppression of NK activity by individual serum samples. which was calculated on the basis of mean \% cytotoxicity shown by age-matehed normal sera used as controls. The mean $\%$ cytotoxicity \pm SD were $37.3 \pm 4.4,33.8 \pm 3.5$, and $30.2 \pm 1.2$, at 5.10 , and $20 \%$ final concentrations of normal serum, respectively. A minus sign $(-)$ indicates enhancement.

${ }^{d}$ Not done.

The gene responsible for the species-specific response to IFN has been mapped on chromosome 21 in man and has been designated as the IFN receptor gene (50, 51). IFN and IL-2 have been used as stimulators of NK cell activity. The susceptibility of target cells to NK lysis may be dependent, in part, upon the ability of effector lymphocytes to produce IFN against the target cells $(52,53)$. Nurmi et al. (29) recently observed that NK activity of DS lymphocytes against K562 target cells was not augmented by IFN to the same levels shown by normal lymphocytes. The present investigation demonstrates that a significant defect is associated with DS lymphocytes in the production of IFN in vitro against K562 target cells (Table 6). Although total PBL in DS patients demonstrate NK activity comparable to that in normal donors, a significantly decreased ability of DS lymphocytes to produce IFN in response to exogenous agents, such as viruses, bacteria, or neoplastic cells, may eventually result in a diminished host immune surveillance against infections and malignancy. The production of IFN against $\mathrm{K} 562$ targets and various IFN inducers in vitro by separated T cells from DS patients as well as the stimulatory effect of IFN on the suppressed NK activity of T lymphocytes remains to be studied. In earlier studies IL-2 was shown to be involved in the production of IFN $(54,55)$. The present investigation demonstrates a defect in DS lymphocytes' response to IL-2, since IL-2-induced cytotoxicity of DS lymphocytes was not augmented to the levels shown by normal lymphocytes (Table 4). Further we examined whether immunologic deficiencies 
observed in DS patients may be due, in part, to active suppressor cell mechanisms, lack of target binding ability, or increased ability of DS lymphocytes to produce culture-induced SSF. It was shown that no inhibition of NK or ADCC activities of normal lymphocytes by DS lymphocyte subpopulations was observed in coculture experiments (data not presented), trisomic lymphocytes exhibited a normal range of target binding capacity (Table 3 ), and the inhibitory effect of culture-induced SSF from DS lymphocytes was also comparable with that of normal lymphocytes. These findings suggest that the deficiencies of NK activity associated with the T-lymphocyte subpopulation, IL-2 and LDCC, and reduced IFN production observed in DS patients are probably due to intrinsic defects in the effector cells rather than due to immunoregulatory dysfunctions. These immunopathologic mechanisms may thus predispose DS patients to repeated infections and possibly to eventual leukemia.

\section{ACKNOWLEDGMENTS}

The authors express their sincere appreciation to Denise DuPrie for her expert secretarial assistance and to Lynette McCurry for her excellent technical assistance.

\section{REFERENCES}

1. Rosner, F., and Lee, S. L., Amer. J. Med. 53, 203, 1972.

2. Miller, R. W., Ann. N.Y. Acad. Sci. 171, 637, 1972.

3. Good, R. A., In "Immune Surveillance" (R. T. Smith and M. Landy, Eds.), p. 445, Academic Press, New York, 1970.

4. Rigas, D. A., Elsasser, R., and Hecht, F., Int. Arch. Allerg. Appl. Immunol. 39, 587, 1970.

5. Rowley, J. D., Lancet 2, 1020, 1981.

6. Oski, F. A., and Naiman, J. L., In "Hematologic Problems of the Newborn," p. 319, W. B. Saunders, Philadelphia, 1972.

7. Sutnick, A. I., London, W., and Blumberg, B. S., Arch. Int. Med. 126, 722, 1969.

8. Adinolfi, J., Gardner, B., and Martin, W., J. Clin. Pathol. 20, 860, 1967.

9. Agarwal, S. S., Blumberg, B. S., Gerstley, B. J. S., London, W. T., Sutnick, A. T., and Loeb. L. A., J. Clin. Invest. 49, 161, 1970.

10. Seger, R., Buchinger, G., and Stroder, J. Eur. J. Pediatr. 124, 77, 1977.

11. Levin, S., Schlesinger, M., Handzel, T., Altman, Y., Czernobilsky, B., and Boss, J., Pediatrics $63,80,1979$.

12. Franceschi, C., Licastro, F., Chircolo, M., Bonette, F., Zanotti, M., Fabris, N., Moccheglani. E., Fantini, M. P., Paolincci, P., and Masi, M., J. Immunol. 126, $2161,1981$.

13. Cederqvist, L. L., Spigelman, S., and Litwin, S. D., Amer. J. Rep. Immunol. 2, 62, 1981.

14. O'Toole. C.. Stejskal, V., Perlmann. P., and Karlson, M.. J. Exp. Med. 139, 457. 1974.

15. Herberman, R. B., and Holden, T., In "Advances in Cancer Research" (G. Klein and S. Weinhouse, Eds.), Vol. 27, p. 305, Academic Press, New York, 1978.

16. Cudkowicz, G., and Hochman, P. S., Immunol. Rev. 44, 13, 1979.

17. Nair, M. P. N., Fernandes, A., Onoe, K., Day, N. K., and Good, R. A., Int. J. Cancer 25, 667. 1980.

18. Nair, M. P. N., and Schwartz, S. A., J. Immunol. 126, $2221,1981$.

19. Shou, L., Schwartz, S. A., Good, R. A., Peng, R., and Chen, C. L., Proc. Natl. Acad. Sci. USA 77, 6096, 1980.

20. Nair, M. P. N., and Schwartz, S. A., J. Immunol. 129, $2511,1982$.

21. Boyum, A., J. Clin. Lab. Invest. 21(97), 77, 1968.

22. Ly, A. I., and Mischell, R. E., J. Immunol. Methods 5, 239, 1974.

23. Berlinger, N. T., Lopez, C.. Lipkin, M., Vogel, J. E., and Good, R. A., J. Clin. Invest 59, 761. 1977. 
24. Gupta. S., Schwartz, S. A.. and Good, R. A., Cell. Inmunol. 44, 242, 1974.

25. Perlmann, P., and Perlmann, H., Cell. Immunol. 1, 300, 1970.

26. Handwerger, B. S., and Koren, H. S., Clin. Immunol. Immunopathol. 5, 272, 1976.

27. Haliotis, T., Roder, J., Klein, M., Ortaldo, J., Fauci. A. S.. and Herberman. R. B.. J. Exp. Med. $151,1039,1980$.

28. Borden, E. C., and Leonhardt, P. H., J. Lab. Clin. Med. 89, 1036. 1977.

29. Nurmi, T., Huttunen, K., Lassila, O., Henttonen, M., Sakkinen. A.. Liisalinna. S.. and Tiiltkainen. A., Clin. Exp. Immunol. 47, 735, 1982.

30. Nair, M. P. N., and Schwartz, S. A., Fed. Proc. 40(abstract). 40. 1981.

31. Mikulski, S. M.. Billing, R., and Terasaki, P. 1.. J. Natl. Cancer Inst. 58. 1485, 1977.

32. Holmes. E. E.. Sibbitt. W. I.., and Bankhurst, A. D. Clin. Res. 32(abstract) 39A. 1984.

33. Lopez, V.. Ochs. H. D.. Thuline. H. C., Dabis, S. D.. and Wedgwood, R. J., J. Pediutr. 86, 207. 1975.

34. Korsager. S. Ugeskr Laeger 143, 1589. 1981.

35. McCulloch, A. J. Ince, P. G.. and Kendall-Taylor, P. J. Med. Genet. 19(3). 232. 1982

36. Esber, H. J., Barbarich, M., Menninger, F. F., Jr., Meshorer, E., Monedjikova, V.. and Rosenkrantz, H.. Amer. J. Clin. Pathol. 59, 872, 1973.

37. Burgio, G. R., and Nespoli. L.. Lancet 2, 1580, 1974.

38. Nurmi, J.. Leinonen. M., Haiva, V. M., Tiilikainen, A., and Kouvalainen, K. Clin. Exp. Immumo. 48(2), 485, 1982.

39. Seger, R., Buchinger. G., and Stroder. J., Eur. J. Pediatr. 124, 77. 1977.

40. Serra, A., Arpaia, E., and Bova, R., Hum. Genet. 41, 157, 1978.

41. Gupta, S., Fernandes. G.. Nair, M.. and Good, R. A.. Proc. Natl. Acad. Sci USA 75, 5137. 1978.

42. Jondal, M., and Merrill, J. E., Eur. J. Immunol. 11, 531, 1981.

43. Grossi. G. E.. Webb, S. R.. Zicca. A.. Lydyard, P. M.. Moretta, L.. Mingari, M. C., and Cooper. M. D., J. Exp. Med. 147, 1405, 1978.

44. Moretta, L., Webb, S. T., Grossi, C. E., Lydyard. P. M.. and Cooper, M. D., J. Exp. Med. 147, 1405. 1978 .

45. Saksela. E., Timonen. T., and Cantell, K.. Sctund. J. Immunol. 10, 257, 1979.

46. Farrar, W. L., Johnson, H. M., and Farrar, J. J., J. Immunol. 126, 1120, 1981.

47. Kall, M. A., and Koren, H. S., Cell. Immunol. 40, 58, 1978.

48. Brunda, M., Varesio, L., Herberman, R. B.. and Holden. H. T., Int. J. Cancer 29, 299, 1982.

49. Spits, H., Borst, J., Terhorst, C., and DeVris. J. E.. J. Immunol. 129, 1563. 1982.

50. Tan, Y. H., Tischfield. J., and Ruddle, F. H., J. Exp. Med. 137, 317, 1973.

51. Epstein. L. B., Lee. S. H. S., and Epstein, C. J., Cell. Immunol. 50, 191, 1980.

52. Santoli, D., Trinchieri, G., and Kaprowski, H., J. Immunol. 121, 532, 1978.

53. Welsh, R. M., Microbiol. Immunol. 92, 83. 1981.

54. Handa, K., Suzuki, R., Matsui. H., Schimizu, Y., and Kumagai, K.. J. Immumol. 130, 988, 1983

55. Northoff, H., Hooks, J. J.. Jordan, G., and Oppenheim, J. J., Beh, Inst. Mitt. 67, 90. 1980.

Received April 20, 1984; accepted with revisions August 4, 1984. 